\title{
Thai Silk Product Industry Development In The Northeastern Region Of Thailand
}

\author{
Nak Gulid, Ph.D., Srinakharinwirot University, Thailand \\ Sirivan Serirat, Suan Dusit Rajabhat University, Thailand \\ Suphada Sirikudta, Srinakharinwirot University, Thailand \\ Udom Sayaphan, Rajamangala University of Technology Thanyaburi, Thailand \\ Aurathai Lertwannawit, Ph.D., Suan Dusit Rajabhat University, Thailand \\ Nongluck Popaijit, Suan Dusit Rajabhat University, Thailand
}

\begin{abstract}
This research aims to study the relationship between independent variables (value, motivation, brand personality, attitude toward product and demographic factor) and dependent variables (purchasing behavior and trend to buy in the future) of Thai silk industry in Northeastern region, Thailand. Quantitative analysis is allowed in this study. This research includes 400 customers who buy Thai silk in two provinces (Roi-Et and Khon-Khen) in the Northeastern region in Thailand. Multiple regression analysis was employed in this study. The result shows that motivation and value are strong influenced on purchasing behavior and trend to buy product in both provinces. However, brand personality and attitude toward product are partially supported our expectations.
\end{abstract}

Keywords: purchasing behavior, trend to buy in the future, motivation, value, brand personality, attitude toward product, Thai silk, Northeastern region

\section{INTRODUCTION}

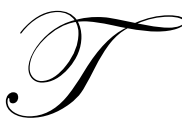

hailand is a country in the Southeast Asia. It produces and exports several products such as rice, tapioca, Thai silk etc. Thailand is a famous place to produce the high quality silk. Thai silk is the labor-intensive industry and creates job and distributes income into the rural area. In the last few years, Thai silk can export to the foreign countries not less than 500 million baht (about 10 million euro) per year (www.dip.go.th). However, foreigners know Thai silk only one brand, which is Jim Thomson. In Thailand, the biggest production source of Thai silk is in the Northeastern region. To develop the quality of Thai silk, it is important to concentrate on the production, design, product development and marketing to allocate efficient resources to produce quality Thai silk product consistent to customer's taste and preference.

To maintain a competitive advantage in silk industry, it is necessary to understand and investigate the impact of all drivers (demographic factors, motivation, brand personality, attitude toward product and value) of purchasing behavior and trend to buy in the future in the content of Northeastern region of Thailand.

\section{RESEARCH INTERESTS}

The main objective of this research is to investigate the impact of the independent variables (demographic factor, motivation, brand personality, attitude toward product and value) to the dependent variables (purchasing behavior and trend to buy in the future) in Thai silk product on the Northeastern region of Thailand.

The following questions are addressed in this research:

1. Are there any impact between the demographic factors and the dependent variables (purchasing behavior and trend to buy in the future)? 
2. Are there any positive relationships between the independent variables (motivation, brand personality, attitude toward product and value) and the dependent variables (purchasing behavior and trend to buy in the future)?

\section{LITERATURE REVIEWS}

\section{Value}

Customer value is very important in relationship marketing and is researched extensively in the 1970s and 1980s (Gutman, 1982). Zeithaml (1988, p.14) develops four consumer definition of value: (1) value is low price; (2) value is whatever I want in a product; (3) value is the quality I get for the price I pay; and (4) value is what I get for what I give. Sirdeshmukh, Singh et al. (2002, p.17) define value as "the customer's perception of the benefits minus the cost of maintaining an ongoing relationship with a service provider". This study follows the definition from Zeithaml (1988) and Sirdeshmukh, Singh et al. (2002). The measure of value includes a four-item scale index on a ten-point scale. The Cronbach's alpha in this study is equal to .9416 .

\section{Attitude toward product}

Traditionally model conceives of attitude as having three components: cognitive, affective, and behavioral. The cognitive dimension involves thoughts or ideas people have about the attitude object, usually referring to beliefs. The affective dimension contains feelings or emotions people experience in regard to the attitude object. The last component, the behavioral dimension of attitude, consists of people's actions with regard to the object (Runyon \& Stewart, 1987). Jacoby and Chestnut (1978) stated that brand loyalty was a function of consumer attitude and behavior. Baldinger and Rubinson (1996) found that attitude toward the brand affected brand loyalty. This study applies three out of five product levels of Kotler (2003) which include core benefit, tangible product, expected product. Additionally, this study includes three additional dimensions: perceived quality, store image and store identity. The measure includes 23 item scale on a seven-point scale. The Conbach's alphas on the six dimensions of attitude toward product: Core benefit $=.8251$, tangible product $=.8448$, perceived quality $=.7948$, expected product $=.8590$, store image $=.8865$ and store identity $=.9288$.

\section{Brand Personality}

Consumers may use certain products or brands to convey a particular image. Within product categories, there are brands that have distinct, images and personality. Brand personality is important because it says something about the person. Therefore, consumers are more likely to select brands with personalities that convey the right image. The little empirical work that was done with brand personality was very introductory or "ad-hoc" in nature (Aaker, 1997). Then in 1977, Aaker (1997) developed a quantitative scale to measure brand personality (Brand Personality Scale). It includes five dimensions: sincerity, excitement, competence, ruggedness, and sophistication. In this study, the measure includes a fifteen-item scale on a seven-point scale. The Cronbach's alphas were calculated for each of the five dimensions: on sincerity dimension (four-item scale) is .8596, on the dimension of excitement (four-item scale) is .9073, on the dimension of competence (three-item scale) is .9090, on the dimension of sophistication (two-item scale) is .8759 and on the dimension of ruggedness (two-item scale) is .8254 .

\section{Motivation}

Motivation is the driving force within individuals that implies them to action. Marketers view motivation as the force that creates consumption. Consumer behaviorists divide motives into rational motives and emotional motives. Rationality implies that consumers select goals based on totally objective criteria such as price, size, etc. Emotional motives imply the selection of goals according to personal or subjective criteria such as fear, status, and so on (Schiffman and Kanuk, 2007)

In this study, rational and emotional motives both include a five-item scale index on a seven-point scale. The reliability value of rational motives is .8321 , whereas emotional motives is .8871 . 


\section{Trend to buy in the future}

Consumers make three types of purchases; trial purchases, repeat purchases, and long-term commitment purchases. Repeat purchase behavior is closely related to loyalty. Consumer loyalty is indicated by an intention to perform a diverse set of behaviors that signals a motivation to maintain relationship with the focal firm, including allocating a higher share of the category wallet to the specific service provider, engaging in positive word-of-mouth and repeat purchasing (Zeithaml Berry et al., 1996). In this study, trend to buy in the future includes a five-item scale index on a seven-point scale. The Cronbach's alpha is .9137, which is a high value (close to 1).

\section{Purchasing behavior}

Purchasing behavior has been examined in terms on types of Thai silk purchased, the number of Thai silk purchased, the amount of money spent on Thai silk, and purchasing styles (Kim, 1997). These variables were used mostly for describing the differences among consumer segments. It includes 14-item scale index (specified only on types of Thai silk purchased) in a seven-point scale. The Cronbach's alpha is .9187 .

\section{CONCEPTUAL FRAMEWORK}

Independent variables $\quad \underline{\text { Dependent variables }}$

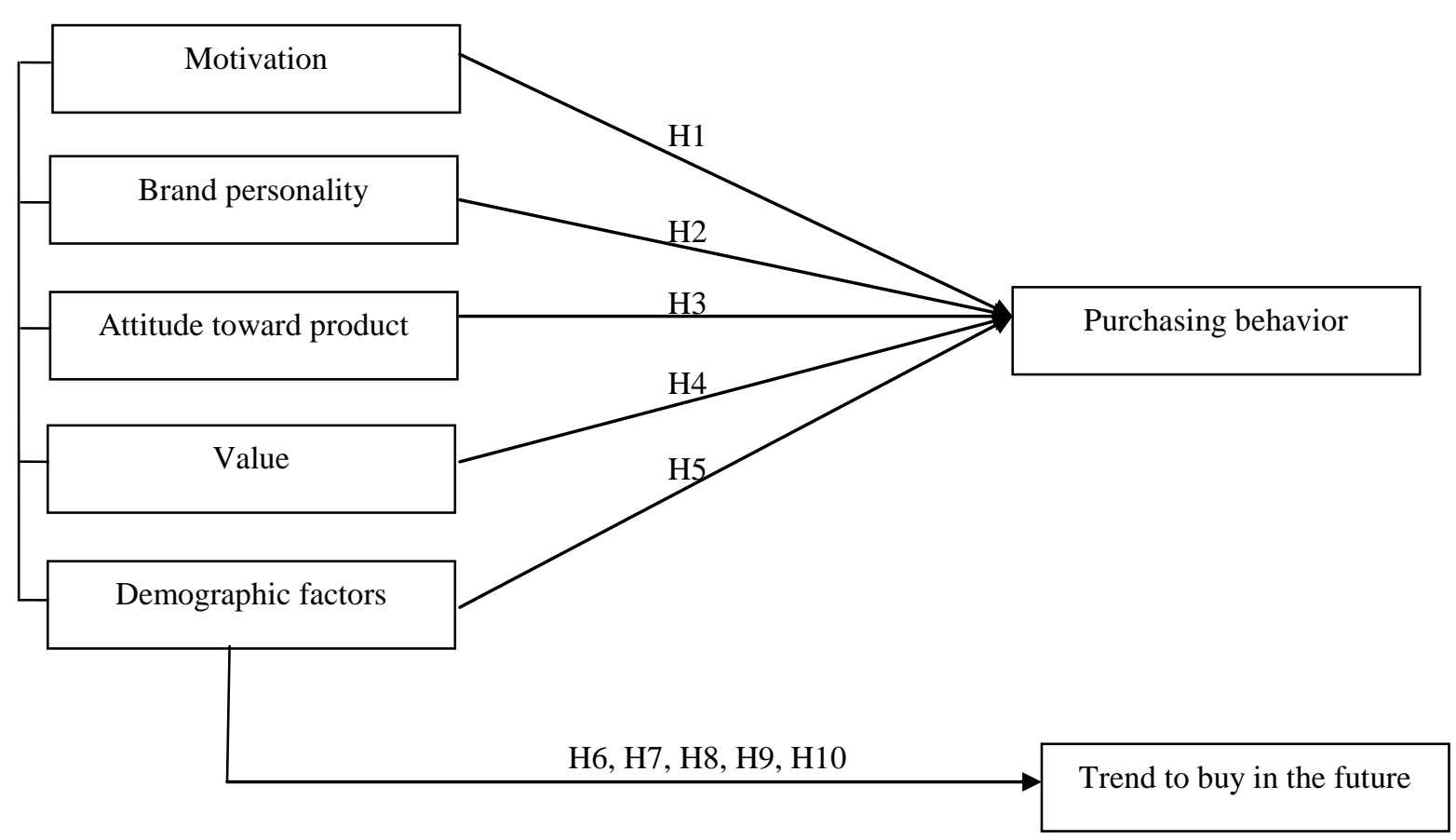

\section{HYPOTHESES}

This section provides the set of hypotheses for testing the determination of purchasing behavior and trend to buy in the future as follows:

H1: There are positive relationships between emotional and rational motives and purchasing behavior.

H2: There are positive relationships between brand personality and purchasing behavior.

H3: There are positive relationships between attitude toward product and purchasing behavior. 
H4: There is a positive relationship between value and purchasing behavior.

H5: There are positive relationships between demographic factor and purchasing behavior.

H6: There are positive relationships between emotional and rational motives and trend to buy in the future.

H7: There are positive relationships between brand personality and trend to buy in the future.

H8: There are positive relationships between attitude toward product and trend to buy in the future.

H9: There is a positive relationship between value and trend to buy in the future.

H10: There are positive relationships between demographic factor and trend to buy in the future.

\section{RESEARCH METHODOLOGY}

This research used quantitative methodology. Survey is conducted to collect data. The following explains the research design used for data collection and hypotheses testing stated previously.

\section{Population}

Customers who buy Thai silk in 2 provinces of the Northeastern region, which are Khon-Khen province and Roi-Et province.

\section{Sample size}

We can find the sample size of each province by using the formula of unknown population size as follows:

$$
\begin{aligned}
& n=\frac{Z_{1-\alpha / 2}^{2}}{4 e^{2}} \\
& Z_{1-\alpha / 2}=1.96 \\
& e=.05 \\
& n=\frac{(1.96)^{2}}{4(.05)^{2}} \\
& =\frac{3.8416}{.01} \\
& =384
\end{aligned}
$$

Hence, we increase the amount of sample size of each province to 400 respondents. The total sample size of this study is equal to 800 respondents.

\section{Sampling method methodology}

Two non-probability sampling techniques, judgmental sampling and convenience sampling are employed in this study. Researcher employs judgmental sampling to select the locations to recruited customers, convenience sampling was also employed for distributing a questionnaire to customers.

\section{RESULT}

\section{Respondent profile}

Questionnaires are distributed to 400 customers in each province. The result shows that the majority of the sample in Roi-Et province is female (80.5\%), age between 31-40 years old (35.8\%), has a monthly average income 
lower than 10,000 baht $(40.8 \%)$ or less than 200 euro, is married (65\%), is government official (54.3\%), works in the operation level (71\%), and is living in Northeastern region $(98.5 \%)$.

The majority of the sample in Khon-Khen province is female (80.5\%), age between 31-40 years old (31.3\%), has a monthly average income between 10,001-20,000 baht (35\%) or between 201-400 euro, is married $(68 \%)$, is government official $(39 \%)$, works in the operation level $(67.3 \%)$, and is also living in Northeastern province $(99.3 \%)$.

The descriptive statistics for purchasing behavior, rational motives, emotional motives, brand personality in 5 dimensions, attitude toward product in six dimensions, value, and trend to buy in the future as composite summated mean scores are calculated as shown in Table 1.

Table 1

Descriptive Statistics of all variables including purchasing behavior, rational motives, emotional motives, brand personality in 5 dimensions, attitude toward product in six dimensions, value, and trend to buy in the future

\begin{tabular}{|c|c|c|c|c|c|}
\hline & & \multicolumn{2}{|c|}{ Roi-Et province } & \multicolumn{2}{|c|}{ Khon-Khen province } \\
\hline \multicolumn{2}{|r|}{$\begin{array}{l}\text { Variable Name } \\
\end{array}$} & Mean & S.D. & Mean & S.D. \\
\hline 1. & Purchasing behavior & 3.88 & 1.22 & 3.64 & 1.40 \\
\hline 2. & Rational motives & 3.95 & 1.46 & 3.52 & 1.54 \\
\hline 3. & Emotional motives & 4.83 & 1.43 & 4.44 & 1.59 \\
\hline 4. & Brand personalities in five dimensions Sincerity & 4.32 & 1.60 & 4.17 & 1.53 \\
\hline 5. & Excitement & 4.00 & 1.66 & 3.85 & 1.63 \\
\hline 6. & Competence & 4.43 & 1.76 & 4.35 & 1.70 \\
\hline 7. & Ruggedness & 4.02 & 1.75 & 4.03 & 1.76 \\
\hline 8. & Sophistication & 4.62 & 1.87 & 4.52 & 1.71 \\
\hline 9. & Attitude toward product in six dimensions Core benefit & 5.30 & 1.37 & 5.12 & 1.37 \\
\hline 10. & Tangible product & 5.26 & 1.40 & 5.06 & 1.38 \\
\hline 11. & Perceived quality & 4.58 & 1.18 & 4.35 & 1.23 \\
\hline & Expected product & 4.71 & 1.38 & 4.63 & 1.40 \\
\hline 13. & Store image & 4.78 & 1.41 & 4.78 & 1.44 \\
\hline & Store identity & 4.93 & 1.35 & 4.91 & 1.32 \\
\hline & Value & 6.44 & 2.27 & 6.34 & 2.04 \\
\hline & Trend to buy in the future & 5.17 & 1.41 & 4.90 & 1.14 \\
\hline
\end{tabular}

\section{Hypotheses Testing}

All variables were analyzed as composite summated mean scores. Multiple regression analysis was used to assess the contribution of purchasing behavior and trend to buy in the future. The results are shown In Table 2 and Table 3 as follows:

Table 2

Multiple regression analysis with Purchasing behavior as dependent variable

\begin{tabular}{|c|c|c|c|c|}
\hline Variables & Roi-Et pr & & Khon-Khen & ince \\
\hline & Standardized estimate & Adjusted $\mathbf{R}^{2}$ & Standardized estimate & Adjusted $\mathbf{R}^{2}$ \\
\hline Emotional motives & $.359^{* *}$ & \multirow{9}{*}{$55.1 \%$} & $.426^{* *}$ & \multirow{9}{*}{$65.7 \%$} \\
\hline Rational motives & $.214 * *$ & & $.324 * *$ & \\
\hline Excitement & & & $.121 *$ & \\
\hline Ruggedness & $.143 * *$ & & & \\
\hline Tangible product & $-.181 * *$ & & $.091 *$ & \\
\hline Perceived quality & $.163 * *$ & & & \\
\hline Store identity & $.118 *$ & & & \\
\hline Value & $.123 *$ & & $.127 * *$ & \\
\hline Gender & & & $-.059 *$ & \\
\hline
\end{tabular}


The results indicate that the hypotheses of $\mathrm{H} 1$ and $\mathrm{H} 4$ are statistically significant in the hypothesized direction as expected in both provinces. The result of Khon-Khen province hypothesized relationship of H3 and H5 which is statistically significant in the opposite direction as expected. However, there is a partially consistent with expectation on $\mathrm{H} 2$ in both provinces. There are only 2 dimensions out of 6 dimensions on attitude toward product and one dimension out of 5 dimensions on brand personality to support the hypotheses on Roi-Et province whereas only one dimension out of five dimensions on brand personality are supported the hypotheses.

The adjusted $\mathrm{R}^{2}$ for Roi-Et province is $55.1 \%$, which implies that emotional motives, rational motives, ruggedness, tangible product, perceived quality, store identity and value can explain $55.1 \%$ of the variance in purchasing behavior. In Khon-Khen province, the adjusted $\mathrm{R}^{2}$ is slightly higher than in Roi-Et province (65.7\%), which indicates that emotional motives, rational motives, excitement, tangible product, value, and gender can explain $65.7 \%$ of the variance in purchasing behavior.

Table 3: Multiple regression analysis with trend to buy in the future as dependent variable

\begin{tabular}{|c|c|c|c|c|}
\hline \multirow[t]{2}{*}{ Variables } & \multicolumn{2}{|c|}{$\begin{array}{l}\text { Roi-Et province } \\
\end{array}$} & \multicolumn{2}{|c|}{ Khon-Khen province } \\
\hline & Standardized estimate & Adjusted $\mathbf{R}^{2}$ & Standardized estimate & Adjusted R ${ }^{2}$ \\
\hline Emotional motives & $.297 * *$ & \multirow{8}{*}{$55.8 \%$} & $.250^{* *}$ & \multirow{8}{*}{$64.7 \%$} \\
\hline Ruggedness & $-.096 *$ & & & \\
\hline Core benefit & $.206 * *$ & & $.208 * *$ & \\
\hline Perceived quality & $.151 * *$ & & & \\
\hline Expected product & & & $.143 * *$ & \\
\hline Store identity & & & $.124 * *$ & \\
\hline Value & $.284 * *$ & & $.243 * *$ & \\
\hline Northeastern residence & $-.075^{*}$ & & & \\
\hline
\end{tabular}

- $* p<0.05, * * p<0.01$

The results are partially supported the hypotheses (H6, H8, H10), excepted for the hypothesized relationship of $\mathrm{H} 9$, which is statistically significant as our expectation. The adjusted $\mathrm{R}^{2}$ are higher than $50 \%$ in both provinces which implies that emotional motives, rugged, core benefit, perceived quality, value, Northeastern residence can explain $55.8 \%$ of the variance in trend to buy in the future for Roi-Et province. Additionally, emotional motives, core benefit, expected product, store image, and value can explain $64.7 \%$ of the variance in trend to buy in the future for Khon-Khen province.

\section{CONCLUSIONS AND RECOMMENDATIONS}

The objective of this research is to empirically investigate the relationships between the independent variables (value, brand personality, motivation, attitude toward product, demographic factor) and the dependent variables (purchasing behavior and trend to buy in the future) in Thai silk industry of Northeastern region in Thailand.

The 10 hypotheses are tested by employing multiple regression analysis. The results indicate that only 2 independent variables (value and motivation) are important in driving purchasing behavior and trend to buy in the future of two provinces in Northeastern region. Furthermore, brand personality and attitude toward product are partially effect on purchasing behavior and trend to buy in the future.

The result is that brand personality includes 5 dimensions, which some dimension is not related to the quality of Thai silk such as sincerity and sophistication. Moreover, on attitude toward product, it includes 6 dimensions, which tangible product dimension has a negative impact on purchasing behavior in both provinces, whereas store image is not related to all dependent variables in this study.

Customers' suggestion to improve Thai silk product in Roi-Et province includes price reduction, product modernization, and difficult to take care on product, respectively. In Khon-Khen province, consumers suggest that 
Thai silk should improve on maintaining Thai silk as cultural product, price reduction and product modernization, respectively.

\section{LIMITATIONS AND FURTHER RESEARCH}

The data of this investigation is derived from the perspectives of customers on Thai silk in Northeastern region, Thailand which is emphasized only a specific segment of Thai silk industry. This narrow focus may limit the generalization to Thai silk industry. This research also employed a cross-sectional design, which is the most frequently applied for descriptive design in research. This design involves the collection of information from any given sample of population elements only once. Hence, the sample does not enable a casual relationship, requiring a longitudinal design to be established. To gain information on purchasing behavior and trend to buy in the future, it is more appropriate to study same sample over time and measure the same variables.

\section{AUTHOR INFORMATION}

Associate Professor Dr. Nak Gulid, full-time lecturer in Business Administration Department, Srinakharinwirot University, received two Ph.D., the first doctoral degree is on International trade and finance, University of Missouri-Columbia, U.S.A., the second doctoral degree is on Marketing, Thammasart Unversity, Thailand. His special area is on Marketing, Management, Economics, international business and Hosptality and tourism. He is a deputy director of MBA program at Srinakharinwirot University. He is a Associate Professor in Management Area. $\mathrm{He}$ is published about 15 papers in several areas such as management, marketing, international business and hospitaltity and tourism.

Associate Professor Sirivan Serirat, full-time lecturer, Graduate school, Suan Dusit Rajabhat University, she was a director of MBA program at Srinakharinwirot University until 2006, her special area is on marketing, international business, Hospitality and tourism. She is a Associate Professor in Business Adminstration Area. She is published about 20 papers in several areas such as mangement, marketing, international business and hospitaltity and tourism.

Associate Professor Supada Sirkudta, full-time lecturer in Business Administration Department, Srinakharinwirot University, she is a Director of MBA program at Srinakharinwirot University since 2006-present, her special area is on Accounting, international business, hospitality and tourism and mangement. She is a Assoicate Professor in Accounting Area. She is published about 15 papers in several areas such as management, marketing, international business and hospitaltity and tourism.

Dr. Aurathai Lertwannawit, full-time lecturer at Suan Dusit Rajabhat Unversity, her special area is on consumer behavior, tourism marketing and mangement, and relational marketing. She received her Ph.D. from Thammasart UNversity in Marketing area. She is published about 7 papers in several areas such as information technology, marketing, international business and hospitaltity and tourism.

Miss Nongluck Popichit, full-time lecturer, Faculty of Management Science, Suan Dusit Rajabhat University, her special area is on management and tourism. She is published about 7 papers in several areas such as mangement, SMEs, and hospitaltity and tourism.

Mr. Udom Sayapunt, full-time lecturer, Marketing Department, Faculty of Business Administration, Rajamangala University of Technology Thanyaburi. He recevied tri- master degrees in management and marketing from Srinakharinwirot University (Thailand) and international marketing from Malardalen University, Sweden. His special area is on marketing, international business, and Tourism. He is published about 10 papers in several areas such as marketing, international business and hospitaltity and tourism.

\section{REFERENCES}

1. Aaker, Jennifer. 1997. Dimensions of brand personality. Journal of Marketing Research, 34 (August), 34756. 
2. Baldinger, Allan L., and Joel Rubinson. 1996. Brand loyalty: The link between attitude and behavior. Journal of Advertising Research, 36 (6), 22-34.

3. Gutman J. 1982. A Mean-End Model based on Consumer Categorization Processes. Journal of Marketing , 48(2), 60-72.

4. Jacoby, Jacob, and Robert W. Chestnut. 1978. Brand loyalty measurement and management, New York: John Wiley\&Sons.

5. Kim, S. (1997). International tourists' souvenir purchasing behavior. Iowa State University, Iowa.

6. Kotler, P. (2003). Marketing Management. $11^{\text {th }}$ ed. New Jersey: Prentice-Hall.

7. Runyon, K.E., \& Stewart, D.W. (1987). Consumer behavior and the practice of marketing (3 ${ }^{\text {rd. }}$ ed.). Columbus, OH: Merrill.

8. Sirdeshmukh, D., Singh, J., and Sabol, B. (2002). Consumer Trust, Value, and Loyalty in Relational Exchanges. Journal of Marketing, 66(1), 15-37.

9. Schiffman, L.G. \& Kanuk, L.L. (2007). Consumer behavior. $9^{\text {th. }}$ ed. New Jersey: Prentice-Hall.

10. Zeithaml, V.A. (1988). Consumer Perceptions of Price, Quality and Value: A Mean-End Model and Synthesis of Evidence. Journal of Marketing, 52 (July), 2-22.

11. Zeithaml, V.A., Berry, L.L., and Parasuraman, A. (1996). The Behavioral Consequences of Service Quality. Journal of Marketing, 60(2), 31.

12. Www.dip.go.th 